\title{
Determining the potential retention of a forest catchment based on the $\mathrm{CN}$ parameter
}

\author{
Michał Wróbel ${ }^{1} \mathbb{D} \cdot$ Andrzej Boczoń $^{1}$
}

Received: 31 July 2020 / Accepted: 3 August 2020 / Published online: 9 August 2020

(c) The Author(s) 2020

\begin{abstract}
Forests play one of the most important roles in the hydrological cycle; as a result, knowledge about the water relations in forest areas should be of great importance in the context of global change. In Poland, the level of groundwater in forest areas has been decreasing for several decades, which negatively affects forest stands. To prevent this, activities have been carried out to increase water resources. Therefore, there is a need to develop a method for prioritizing the locations of retention investment projects. While searching for simple methods to achieve this goal, it was assumed that retention facilities should be located first in the partial catchments with the greatest possible retention capacities. This value, which is called the potential retention of the catchment, can be calculated using the $\mathrm{CN}$ parameter, which is used in the soil conservation service-curve number (SCS-CN) method. The CN parameter contains information on the type of land cover, the type of soil, and the moisture content. The source of the obtained land-use data was the Corine Land Cover (CLC) database, which was developed by the European Environment Agency for the area of the European Union. The analyses were carried out on the forest catchment of the Łutownia River, which is located in the Białowieża Primeval Forest.
\end{abstract}

Keywords Forest $\cdot$ Retention $\cdot \mathrm{CN}$ parameter $\cdot$ Water management

\section{Introduction}

Given that climate change contributes to increased air temperatures and decreased rainfall, water scarcity may become one of the biggest social problems in the near future. Among all ecosystems, forests play one of the most important roles in the hydrological cycle; therefore, knowledge about the water relations in forest areas should be of great importance in the context of preventing global climate change. Forests play a particularly strong role in regulating runoff in small catchments where the forest covers over $50 \%$ of the total catchment area (Scholz et al. 2015). In addition, if all small catchments in a larger catchment area are managed to retain water, the effects of potential floods can also be reduced (Schüler 2005). Unfortunately, the groundwater levels in forest areas have been decreasing in Poland for several decades, which adversely affects forest stands (Mioduszewski 2008; Frydel and Miler 2014; Wróbel et al. 2016). For this reason,

Michał Wróbel

M.Wrobel@ibles.waw.pl

1 Department of Forest Ecology, Forest Research Institute, ul. Braci leśnej 3, 05-090 Sękocin Stary, Poland at the end of the 1990s, programs began to be implemented to increase the surface and groundwater retention in forest (Matczak et al. 2019). As part of this effort, modernization is planned for small reservoirs and the structures damming drained wetlands; where possible, restoration of the natural river paths and the leveling and slowing of the flow of flood waters are planned. For this reason, there was a need to develop a method for prioritizing the locations of retention investment projects, e.g., in a group of partial catchments of a selected river catchment. In searching for relatively simple methods to achieve this goal, it was assumed that retention facilities should be located first in the partial catchments with the greatest possible retention. The retention capacity can be calculated using a relatively simple SCS-CN model. The Łutownia River catchment was chosen as a methodical example.

\section{Methodology}

The SCS-CN method was used to determine the potential capacities of the partial catchments. This method was created in USA in the 1950s and has since been one of the 
most common methods for determining effective precipitation. The method was originally developed mainly for agricultural areas, but has been modified and successfully used over the years in various regions and climatic conditions (Ara and Zakwan 2018; Kim et al. 2018; Lal et al. 2016; Mishra et al. 2003) including forest areas (Soulis 2018; Vojtek and Vojteková 2016). In this method, the effective rainfall depends on the type of soil, the soil use, the nature of the plant cover, and the moisture content. All these features are included in the $\mathrm{CN}$ parameter. To determine the $\mathrm{CN}$ parameter, among others, the land-use category should be specified. The Corine Land Cover method was chosen for this purpose (Büttner and Kosztra 2007). However, it contains fairly general information on forest areas. Forest areas were divided into broad-leaved forests, coniferous forests, and mixed forests. For more accurate calculations, specific data are required; hence, in Poland, a modification was used that was more detailed than in the original and used such terrain categories as managed forests, forest glades, windfall forests, forest roads, and young forests (Ciepielowski et al. 2002). A method was also developed for the commercial forests using a parameter applied in forest management, viz., the so-called tree cover (Miler 2012; Wróbel et al. 2020). The SCS-CN method is based on the water balance equation and the two following assumptions: the equality of total precipitation and the sum of the initial losses, current infiltration, and effective precipitation; and the equality of the quotient of the effective precipitation and the total precipitation reduced by the initial losses and the quotient of current infiltration and the maximum potential retention of the catchment (Rallison and Miller 1981; Mishra et al. 2003):

The maximum potential retention $S$ is calculated in $\mathrm{mm}$ depending on the $\mathrm{CN}$ parameter and is expressed by the following formula:

$S=25.4 \times\left(\frac{1000}{\mathrm{CN}}-10\right)[\mathrm{mm}]$

The determination of the $\mathrm{CN}$ parameter in the area of the forest river catchment was carried out on the example of the Łutownia River in the Białowieża Primeval Forest in north-eastern Poland. Due to the limitations of the SCS method (Ponce and Hawkins 1996), a lowland catchment area of $121 \mathrm{~km}^{2}$ was selected for the analysis. The river catchment was divided into nine sub-catchments according to the hydrographic map of Poland (Fig. 1), which is a database on the hydrography of Poland. The Corine Land Cover was chosen as the basis for determining a land-use category in the partial catchment areas of the Łutownia River. The land-cover classes in the CLC database were divided into three levels. The first level included five main types of terrestrial land cover: agricultural areas,

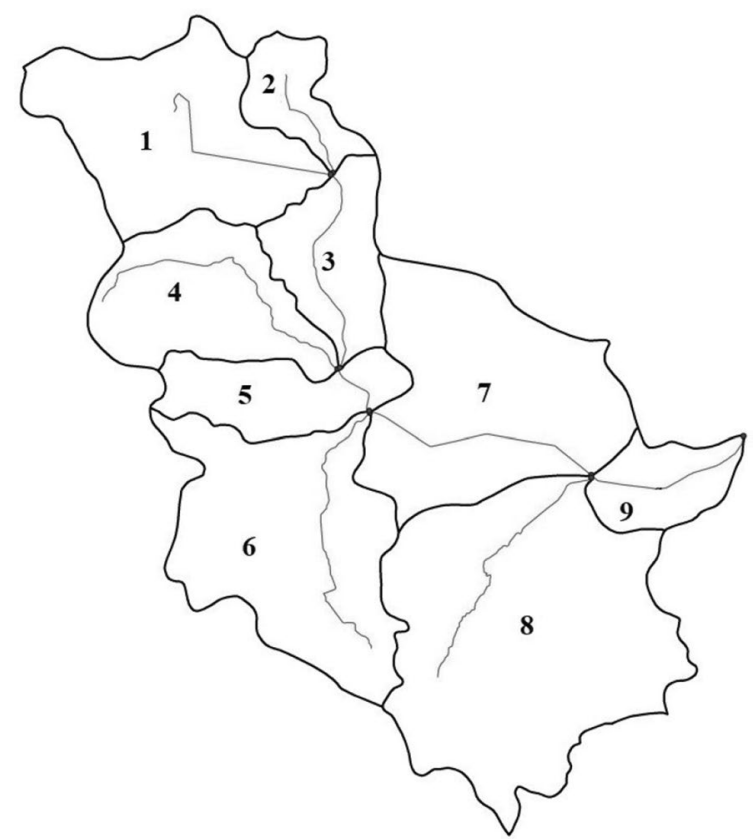

Fig. 1 Division of the Eutownia catchment area into partial catchments along with a river network

anthropogenic areas, forests and semi-arid areas, wetlands, and water bodies. Within the second level, 15 forms of land cover were classified, which can be represented on the maps at scales from 1:500,000 to 1:1,000,000. Finally, 44 classes were distinguished on the third level. This level of detail was based on the land-cover databases in all European countries. The land-cover parameters for the discussed studies were estimated according to Corine Land Cover, which was modified to consider the degree of tree cover (Miler 2012). Soil is another factor affecting the $\mathrm{CN}$ parameter. Four soil groups were distinguished according to the permeability criterion. Group A includes the most permeable soils, and group D includes the soils with high clay contents. The average humidity conditions were calculated for the Eutownia River catchment. The soil group was determined for each of the 4944 designated areas according to the data from the State Forests IT System. Each area was also sorted by the degree of tree cover.

\section{Results}

Based on the weighted average, the share of precipitation in each soil group was determined, and the share of precipitation was determined depending on the tree cover in that area. Finally, based on the weighted average, the $\mathrm{CN}$ parameters were determined depending on the soil type, land-cover, and moisture conditions. The calculated values of the $\mathrm{CN}$ parameter for the individual partial catchments ranged from 
Table 1 The CN parameters and potential retention for the Łutownia river catchment

\begin{tabular}{lll}
\hline Catchment & CN parameter & $\begin{array}{l}\text { Catchment } \\
\text { potential reten- } \\
\text { tion }\end{array}$ \\
\hline 1 & 43 & 337 \\
2 & 46 & 298 \\
3 & 38 & 414 \\
4 & 40 & 381 \\
5 & 41 & 366 \\
6 & 45 & 310 \\
7 & 47 & 286 \\
8 & 44 & 323 \\
9 & 54 & 216 \\
\hline
\end{tabular}

38 to 54 . The lowest values were recorded in the northern part of the catchment (Table 1). Based on the $\mathrm{CN}$ values, the potential retention capacities of the partial catchments were calculated. The calculated values were between 216 and $414 \mathrm{~mm}$. According to the obtained values, the retention facilities should be arranged first in the partial catchments numbered 3-5, which are located in the central part of the catchment (Table 1).

The final stage of the procedure for prioritizing the locations of retention facilities was to develop a map that illustrated the grouping of the partial catchments depending on the calculated potential retention capacities. Five potential retention classes were adopted (Fig. 2). Low priorities for retention investment projects were assigned to areas with values below $250 \mathrm{~mm}$ and high priorities were assigned for those above $400 \mathrm{~mm}$, accordingly.

\section{Discussion}

The basic principle of retention should be to retain and properly allocate as much water in the landscape as possible and for the longest period of time, especially in the spring. Measures to retain water in forests must take into account different terrain conditions, meteorological conditions, and the state of the soil water balance. The effectiveness of retention measures varies depending on the precipitation and site characteristics. For this reason, it is important to properly arrange retention devices in the catchment areas. The analysis for the planning of retention facilities indicated that the lack of simple methods for arranging the layout of retention facilities in forest habitats on the catchment scale. This value can be calculated using the relatively simple SCS-CN method. The potential retention values obtained depend on the area in which we perform the analysis. The Corine LandCover method used to calculate the $\mathrm{CN}$ parameter is considered the most effective (Borowicz et al. 2011; Banach 2012). The analyses performed allowed us to state that the SCS-CN method can be used to determine the potential retention in partial catchments when deciding the locations of retention facilities.
Fig. 2 Division of the partial catchments according to the calculated potential retention capacities

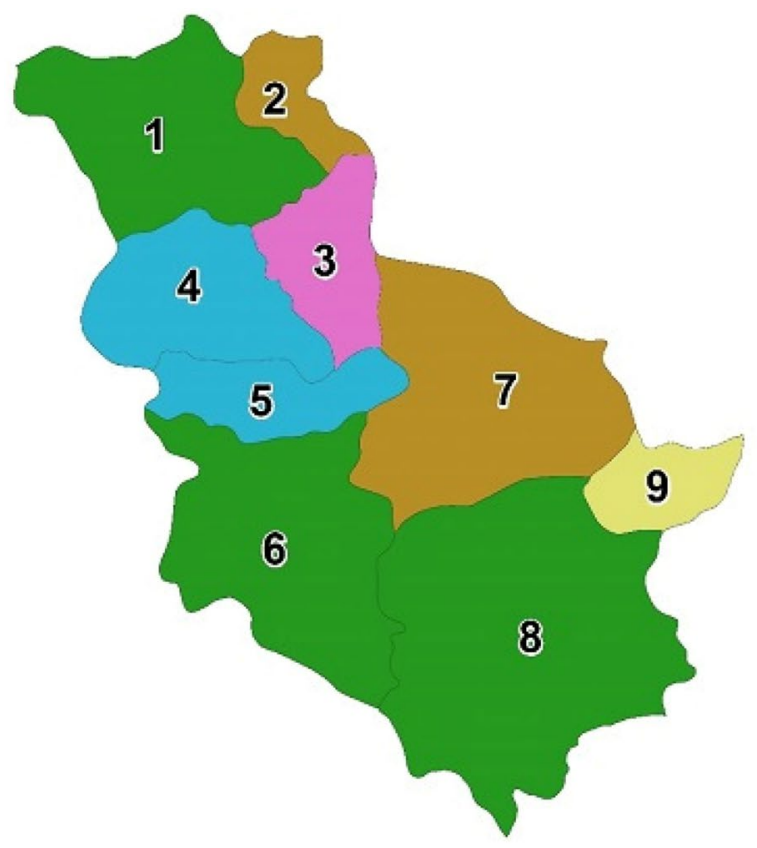

Low priority

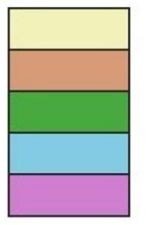

$<250 \mathrm{~mm}$

$251-300 \mathrm{~mm}$

$301-350 \mathrm{~mm}$

$351-400 \mathrm{~mm}$

$>400 \mathrm{~mm}$

High priority 
Open Access This article is licensed under a Creative Commons Attribution 4.0 International License, which permits use, sharing, adaptation, distribution and reproduction in any medium or format, as long as you give appropriate credit to the original author(s) and the source, provide a link to the Creative Commons licence, and indicate if changes were made. The images or other third party material in this article are included in the article's Creative Commons licence, unless indicated otherwise in a credit line to the material. If material is not included in the article's Creative Commons licence and your intended use is not permitted by statutory regulation or exceeds the permitted use, you will need to obtain permission directly from the copyright holder. To view a copy of this licence, visit http://creativecommons.org/licenses/by/4.0/.

\section{References}

Ara Z, Zakwan M (2018) Estimating runoff using SCS curve number method. Int J Emerg Technol Adv Eng 8(5):195-200

Banach W (2012) Wpływ zastosowania rastrowej mapy Corine Land Cover na średnią wartość parametru CN modelu SCS. Czasopismo Techniczne Środowisko 4:3-11

Borowicz E, Kozak M, Madzia M (2011) Wpływ metody pozyskiwania informacji o zagospodarowaniu terenu na wartość wyznaczonego opadu efektywnego. Nauka Przyroda Technol 5(4):1-7

Büttner G, Kosztra B (2007) CLC 2006 technical guidelines. EEA Technical report No 17, p 60

Ciepielowski A, Wójcik J, Banasik K (2002) Adaptation of the SCS unit hydrograph method to the conditions in Polish forests. In: Proceedings of the 5th international conference on hydro-science and engineering, Warsaw, pp 1-10

Frydel K, Miler AT (2014) Zmiany stanów wód gruntowych na tle zmian klimatycznych w Nadleśnictwie Kaliska. Infrastruct Ecol Rural Areas II(3/2014):743-755. https://doi.org/10.14597/infra eco.2014.2.3.055

Kim J, Johnson L, Cifelli R, Choi J, Chandrasekar V (2018) Derivation of soil moisture recovery relation using soil conservation service (SCS) curve number method. Water 10(7):833. https://doi. org/10.3390/w10070833

Lal M, Mishra SK, Pandey A, Pandey RP, Meena PK, Chaudhary A, Kumar Y (2016) Evaluation of the soil conservation service curve number methodology using data from agricultural plots. Hydrogeol J 25:151-167. https://doi.org/10.1007/s10040-016-1460-5

Matczak P, Takacs V, Goździk M (2019) Reversing the current: small scale retention programs in polish forests. In: Hartmann
T, Slavíková L, McCarthy S (eds) Nature-based flood risk management on private land, disciplinary perspectives on a multidisciplinary challenge. Springer, Cham, pp 23-37. https://doi. org/10.1007/978-3-030-23842-1_3

Miler AT (2012) Ocena wpływu zmian użytkowania terenu na odpływy wezbraniowe przy użyciu metody SCS-CN. Rocznik Ochrony Środowiska 14:512-524

Mioduszewski W (2008) Mała retencja w lasach elementem kształtowania i ochrony zasobów wodnych. Stud Mater Centrum Edu Przyrodniczo-Leśnej 1(18):33-48

Mishra SK, Singh VP, Sansalone JJ, Aravamuthan V (2003) A modified SCS-CN method: characterization and testing. Water Resour Manag 17:37-68

Ponce VM, Hawkins RH (1996) Runoff curve number: has it reached maturity? J Hydrol Eng 1(1):11-19. https://doi.org/10.1061/ (ASCE)1084-0699(1996)1:1(11)

Rallison RE, Miller N (1981) Past, present, and future SCS runoff procedure. In V.P. Singh (ed.) Rainfall-runoff relationships. Proceedings, international symposium on rainfall-runoff modeling. Mississippi State University, pp 353-364

Scholz M, Mimikou M, Kasperidus HD, Bastrup-Birk A, Baltas E, Tekidou A, Bariamis G, Zal N (2015) European Environment Agency water retention potentials of Europe's forests. A European overview support to natural water retention measures, $\mathrm{p} 41$. https ://doi.org/10.2800/790618

Schüler G (2005) The European trans-national project "Water Retention by Land-Use" (WaReLa). Presentation at the XXII IUFRO World Congress, Brisbane, Australia. Int For Rev 7(5):323

Soulis KX (2018) Estimation of SCS curve number variation following forest fires. Hydrol Sci J 63(9):1332-1346

Vojtek M, Vojteková J (2016) GIS-based approach to estimate surface runoff in small catchments: a case study. Quaest Geogr 35(3):97-116

Wróbel M, Boczoń A, Gawryś R, Kowalska A, Krysztofiak-Kaniewska A (2016) The effect of beaver activity on artificial impoundment on the Braszcza River in the Białowieża primeval forest. Balt For 22(1):46-50

Wróbel M, Mańk K, Krysztofiak-Kaniewska A (2020) Applying the stocking index to the determination of the curve number parameter in the forest catchment area. Nat Resour Model 33:e12241. https ://doi.org/10.1111/nrm.12241

Publisher's Note Springer Nature remains neutral with regard to jurisdictional claims in published maps and institutional affiliations. 